\title{
BUILDING AN EARLY WARNING TOWARDS THE RESILIENCE OF ISLAMIC BANKING IN INDONESIA
}

\author{
Dimas Bagus Wiranatakusuma ${ }^{1}$, Jarita Duasa ${ }^{2}$
}

\begin{abstract}
Building an Early Warning Towards the Resilience of Islamic Banking in Indonesia. An early warning system (EWS) is widely used as surveillance mechanism for preserving financial system stability. This paper addresses the issue of namely which macroeconomic indicators that are capable of signaling adverse shocks towards the resilience of Islamic banking in Indonesia. This research uses an extraction signal approach as EWS mechanism. The results suggest that there are several indicators that (1) IBRI, which is composed from standardized deposit and financing, is able to figure out the resilience of Islamic banking. The resilience of Islamic banking was considered stable since the index was moving below the normal line during the global financial crises, and (2) Some selected macro financial indicators, M2/reserve (M2res), credit growth (CG), real effective exchange rate (REER), and inflation rate (INF) empirically show low noise to signal ratio. It means that these four variables are capable of signaling vulnerabilities due to adverse external shocks. The paper recommends that the resilience of Islamic banking needs to be supported by the resilience in the real sector.
\end{abstract} Keywords: early warningsystem, resilience of Islamic banking, extraction signal approach.

\begin{abstract}
Abstrak. Membangun Peringatan Dini Menuju Ketahanan Perbankan Islam di Indonesia. Sistem deteksi dini banyak digunakan sebagai mekanisme surveillans guna menjaga stabilitas sistem keuangan. Tulisan ini membahas isu terkait dengan manakah indikator makroekonomi yang mampu mengeluarkan sinyal karena tekanan eksternal kaitannya terhadap ketahanan perbankan syariah. Tulisan ini menggunakan pendekatan ekstraksi sinyal sebagai mekanisme sistem deteksi dini. Hasil penelitian ini menyarankan bahwa beberapa indikator, yaitu pertama, IBRI yang terdiri dari simpanan dan pembiayaan yang sudah distandarisasi, mampu menggambarkan tingkat ketahanan perbankan Syariah yang bervariasi. Pada tahun 2004, tingkat ketahanan perbankan Syariah menurun, namun secara bertahap membaik dan stable hingga tahun 2016. Tingkat ketahanan perbankan Syariah menunjukkan arah yang stabil karena IBRI bergerak dibawah garis hijau selama krisis global. Kedua, beberapa indikator makro terpilih, yaitu M2/reserve (M2res), pertumbuhan kredit (CG), real effective exchange rate (REER), dan tingkat inflasi (INF), secara empiris menunjukkan ratio signal to noise yang rendah. Ini berarti indikator terpilih tersebut mampu menjadi indikator utama dalam mengeluarkan sinyal kerentanan karena adanya tekanan eksternal. Akbirnya, tulisan ini memberikan rekomendasi bahwa ketahanan perbankan Syariah perlu didukung oleh ketahanan di sektor riil mengingat basis usahanya adalah pengembangan sektor riil.
\end{abstract}

Kata kunci: sistem deteksi dini, ketahanan perbankan Syariah, pendekatan ekstraksi sinyal 


\section{Introduction}

Islamic banking operation in Indonesia was started in 1992 when the first full-fledged Islamic bank was established, Bank Muamalat Indonesia. This Islamic bank provely survived from the 1998 Asian financial crisis without any government assistance. The growth of Islamic banking proliferated rapidly after the new banking act was officially stipulated in 1998. Afterwards, the Islamic banks operations become widely expanded and well-accepted by all level of society in Indonesia. The growth of Islamic banking industry can be traced back from growth on its asset, deposit, and financing side. In terms of asset, it grew drastically from only IDR 21 trillion or $0.17 \%$ share out of total assets in the banking industry in 2005 to IDR 242 trillion or $4.89 \%$ out of total asset in banking industry in 2013. In terms of deposit, it increased from only IDR 16 trillion in 2005 to IDR 184 trillion in 2013. Likewise, in terms of financing side, there was a significant increase from only IDR 15 trillions in 2005 to IDR 184 trillion in 2013. Overall, asset, deposit, and financing grew steadily on average at 30\% over the year 2005 to 2013.

There are two main risk assessments conducted by Bank Indonesia (BI) on Islamic banking, financing risk and liquidity risk. In terms of financing risk, in semester I 2015, the growth of gross Non-performing Financing (NPF) had dropped significantly from $65.15 \%$ in semester II 2014 to $20.79 \%$. This condition is driven by a successful domestic banking consolidation, namely the adjustment of financing-to-Value (FTV) which enable banking industry aggresively to extend the financing towards value-added economic sectors for generating economic growth. However, the nominal NPF increased slightly in semester I around 4.72\%, from $4.33 \%$ in semester II 2014. In general, according to financing risk assessment, the resilience of Islamic banking is on alert condition NPF ratio almost reaches the stipulated tolerance limit of BI around maximum at 5\% (BI Regulation No 15, year 2013).

In terms of liquidity risk, Islamic banks faced a decrease liquidity ratio in semester I 2015. It was shown by dropping the ratio of liquid tools, namely liquid asset (LA) over negotiable certificate of deposit or banking deposit guarantee (NCD), and liquid asset (LA) over deposited funds (DPK), from $98.16 \%$ and $16.31 \%$, in semester II 2014 to $71.30 \%$ and $12.60 \%$, respectively in semester I 2015. A higher of ratios indicate that Islamic banking is having a sufficient liquid assets over the liabilities, or in other words Islamic banks are capable of avoiding and minimizing liquidity mismatch arising from banking operations. In this case, Islamic banking may expose to liquidity risk due to a decreased in the amount of liquid assets.

The resilience of Islamic banking can be defined as the ability of Islamic banking to resist adverse shocks originated from macroeconomic factors, so this 
ability can preserve the soundness of its balance sheet. The adverse shocks are exogenous shocks which then damage the resilience of Islamic banking due to incomplete markets in financial system. Incomplete markets denote a condition where markets become incapable to hedge all possible risks exposed into them. This incomplete market may create financial fragility, contagion, and bubbles in financial system due to the shocks are not smoothly absorbed. Likewise, Islamic banking can fall into default as its inability to withstand amplified shocks, shown by deterioration in its balance sheet. Given that the financial system is interconnected, the failure in Islamic banking can create panic behavior in the markets and ultimately encourage bank-run. The balance sheet then becomes worst as shocks become endogenously deteriorating. A situation which makes Islamic banking fail and may trigger a larger crisis, expressed in a general worsening of Islamic banking's balance sheets, is due to a deterioration of the macroeconomic environment. On this regards, major crises in financial system cannot simply be avoided from macroeconomy stability due to there is a dynamic interaction between financial system - which Islamic banking is part of it - and macro conditions. Therefore, unanticipated response from financial system in absorbing shocks from macroeconomic environment can make Islamic banking fail and may cause chain reactions in a tightening surrounding, including worsening of bank's balance sheet.

The current study aims to identify which macroeconomic variables are capable of signaling adverse shocks towards the resilience of Islamic banking in Indonesia. This study uses the simple approaches in EWS mechanism as surveillance tools for the resilience of Islamic Banking in Indonesia.

\section{Literature Review}

The development of the leading indicators of banking distress and earlywarning systems has long been a main interest of central banks and academics. Studies on this were written by Caprio and Klingebiel (1996), Lindgren et al. (1996), Sachs et al. (1996), Honohan (1997), Eichengreen and Rose (1998), DemirgüçKunt and Detragiache (1998, 2000), Hardy and Pazarbasioglu (1999), Glick and Hutchison (2001), González-Hermosillo (1999), Kaminsky and Reinhart (1999), Duttagupta R. and P. Cashin (2011), Davis and Karim (2008). In practice, there are approaches commonly used to deal with early warning system (EWS), including non-parametric and parametric approaches.

Among those, Eichengreen and Rose (1998) use multivariate Probit regression for understanding the role of international shocks in determining banking crises in developing and emerging economies. They find that interest rate shocks stemming from OECD countries as well as their GDP growth rate have a significant and 
strong effect on bank fragility in developing countries. Hutchison (2002) estimates multivariate Probit models linking the probability of banking risks to domestic macroeconomic variables and institutional characteristics. He finds that the following variables are strongly and significantly associated to banking crisis: inflation, GDP growth, exchange rate turbulence 1 as well as variables describing the characteristics of the financial and the regulatory environments. Demirgüç-Kunt and Detragiache (1998) find that low GDP growth, high real interest rates, and high inflation are significantly correlated with the occurrence of a banking crisis. Demirgüç-Kunt and Detragiache (2000) compare the results with the signal approach of Kaminsky and Reinhart (1999), and show that their model performs better in terms of in-sample prediction.

Yucel (2011) did some observations regarding a non-exhaustive collection of the early warning literature from 1971 to 2011. In terms of the methodologies, binary dependent variable (the logit analysis) has been the most popular used, meanwhile signal extraction analysis shares the second place.

In the literature, large number of empirical investigations has been carried out using multivariate logit or probit models for developing banking distress leading indicators. Wong et.al (2007), for example, developed a probit econometric model to identify a set of leading indicators of banking distress and estimate banking distress probability for Hong Kong and other EMEAP (Executives' Meeting of East Asia and Pacific Central Banks ) namely Australia, China, Indonesia, Japan, Korea, Malaysia, New Zealand, the Philippines, Singapore, and Thailand economies. Macroeconomic fundamentals, currency crisis vulnerability, credit risk of banks and companies, asset price bubbles, credit growth, and the occurrence of distress of other economies in the region are found to be important leading indicators of banking distress in the home economy. A case study of Hong Kong based on the latest estimate of banking distress probability and stress testing results shows that currently the banking sector in Hong Kong is healthy and should be able to withstand well certain possible adverse shocks. The study also finds that banking distress is contagious, suggesting that to be effective in monitoring banking distress, close cooperation between central banks should be in place.

Further, Wong et.al (2010) developed a panel probit econometric model to identify the leading indicators of banking distress and to estimate the banking distress probability for EMEAP economies. Macroeconomic fundamentals, currency crisis vulnerability, credit risks of banks and non-financial companies, asset price gaps, credit growth, and the occurrence of distress in other economies are found to be important leading indicators.

Matthieu Bussiere and Marcel Fratzscher 2006) developed an early warning 
system (EWS) model, based on a multinomial logit model, for predicting financial crises. It is shown that commonly used EWS approaches, which use binomial discrete-dependent-variable models, are subject to what we call a post-crisis bias. We show that applying a multinomial logit model, which allows distinguishing between more than two states, is a valid way of solving this problem and constitutes a substantial improvement in the ability to forecast financial crises. The empirical results reveal that, for a set of 20 open emerging markets for the period 1993-2001, the model would have correctly predicted a large majority of crises in emerging markets.

Another commonly adopted approach is the signal extraction approach. Extraction signal approach produced variable importance rankings that can be used in the stepwise specifications of logistic regression. This nonparametric approach makes fewer assumptions about the underlying populations, less sensitive to outlying observations, and easier for practitioners to understand. This approach was elaborated by Kaminsky and Reinhart (1996) by evaluating the usefulness of several leading indicators in signaling an impeding crisis. Related to this approach, Gurnain et.al (2013) focused on a quantitative method to identify vulnerabilities, specifically an imbalance indicator model and its application to Canada. The model proves useful for isolating historical imbalances that could be indicators of financial system vulnerabilities. It complements other sources of information, including market intelligence and regular monitoring of economic and financial data.

Manasse et.al (2013) employed a recent statistical algorithm (CRAGGING) in order to build an early warning model for banking crises in emerging markets. They perturb the data set many times and create "artificial" samples from which we estimated our model, so that, by construction, it is flexible enough to be applied to new data for out-of-sample prediction. The study finds that, out of a large number (540) of candidate explanatory variables, from macroeconomic to balance sheet indicators of the countries' financial sector, they can accurately predict banking crises by just a handful of variables. Using data over the period from 1980 to 2010, the model identifies two basic types of banking crises in emerging markets: a "Latin American type", resulting from the combination of a (past) credit boom, a flight from domestic assets, and high levels of interest rates on deposits; and an "Asian type", which is characterized by an investment boom financed by banks' foreign debt. The model is compared to other models obtained using more traditional techniques, a Stepwise Logit, a Classification Tree, and an "Average" model, and they find that their model strongly dominates the others in terms of out-of-sample predictive power. 


\section{Methods}

This paper empirically identifies some selected macroeconomic variables that can affect the resilience of Islamic banking. An extraction signal approach is used to examine the resilience of Islamic banking. This approach was initially elaborated by Kaminsky and Reinhart (1996) which later is called an early warning system (EWS). Technically, EWS mechanism evaluates the ability of several variables in signaling a crisis at a certain period of time. This approach is considered as a non parametric approach since it involves monitoring the evolution of a number of economic variables through signaling approach. Therefore, the EWS monitors behavior of variables which usually departs from "normal/tranquil" in the period preceeding a crisis. Deviations of these variables from their "normal" level beyond a certain threshold value are considered as sending a warning" signal" of a crisis within a specified period.

Given that an extraction signal is a non-parametric approach, hence this study provides some stages for building EWS through signal approach, as follows:

\section{Defining the Islamic Banking Resilience Index (IBRI)}

A bank is exposed to some risks due to its operations which is connected with its assets and liabilities positions. These risks can trigger instability in the financial system as bank is the main player in financial intermediaries. In the context of Islamic banks, some possible risks which are potentially exposed due to external shocks on Islamic banking are: (1) liquidity risk due to the presence of massive bank run; and (2) credit risk due to rising non-performing loans triggered by excessive risk taking behavior. Some studies incorporated massive bank run, withdrawals (Diamond and Dybvig, 1983), and lending booms (Hanohan, 1997) becoming among the most important causes that affecting the resilience of banking system, including in Islamic banking. In respect to maintain the resilience of Islamic banking, this paper develops an Islamic Banking Resilience Index (IBRI) in order to support monitoring tasks by incorporating some components. The components are intended to display the relative importance of the various risks in the composition of the IBRI.

There are two important risks covered in the IBRI, namely liquidity and credit risk. Credit risk relates with the banking operation in the midst high non performing loans. Banks are financial intermediaries whose liabilities are mainly short-term deposits and whose assets are considered short and long term. When the value of banks' assets fall short of the value of their liabilities, banks can be trapped into insolvent situation. This fall is mainly due to incapability of borrowers 
to fulfill their current and future obligations and ultimately can affect the fall in banks' assets. Thus, credit risk can occur due to borrowers do not fulfill their obligations. In addition, given that banks are difficult due to borrowers' default, liquidity problems start to emerge. Capital position would be affected as banks need immediate injection to preserve its operation and mitigate systemic risk further arises. This situation may attract some deposits withdrawal from the banks' account. The problems are compounded if the deposits withdrawal are in massive numbers. Therefore, credit risk is perceived as triggering factor in causing liquidity risk.

According to credit and liquidity risks exposure, a monthly IBRI is developed and used to investigate whether Islamic banking is under normal or crisis condition. For the analysis, IBRI is composed by two variables, (1) deposits (DEP), and (2) financings (FIN). DEP variable is obtained from total of demand, saving, and time deposit collected by Islamic banks. In addition, FIN variable is obtained from total of various type of financings by Islamic banks.

\section{Defining a signal and crisis}

Let assume $\mathrm{i}=\mathrm{a}$ univariate variable, $\mathrm{j}=\mathrm{a}$ particular country, $\mathrm{S}=$ signal variable, and $\mathrm{X}=$ variable. $\mathrm{A}$ variable relates to variable $\mathrm{i}$ and country $\mathrm{j}$ is expressed by $X_{i}^{j}$ and the threshold for this variable is denoted $X_{*}^{j}$ as. Then, a signal variable that relates to indicator $\mathrm{i}$ and country $\mathrm{j}$ is denoted by $S_{i}^{j}$. The binary model is then developed, where $S_{i}^{j}=(0,1)$, and if the variable crosses the stipulated threshold, a signal is emitted, $S_{i}^{j}=1$.

\section{Interpreting a signal and signal}

Once the crisis and signal are defined, the evaluation criteria can be conducted by using matrix signal-crisis framework. Kaminsky, et. al (1998) developed matrix crisis-signal framework by using 24 months as signal horizon. In this matrix, $A$ is the number of months in which the indicator issued a good signal, B is the number of months in which the indicator issued a bad signal or "noise" due sent a false signal, $\mathrm{C}$ is the number of months in which the indicator failed to issue a warning signal, and $\mathrm{D}$ is the number of months in which the indicator does not issue a signal and a crisis does not occur. According to Kaminsky, et. al (1998), a perfect indicator would only produce observations that belong to the north-west and south-east cells of this matrix (A and D). It would issue a signal in a particular month that is to be followed by a crisis (within the next $\mathrm{n}$ months, example 24 months), so that $\mathrm{A}>$ 0 and $\mathrm{C}=0$, and it would refrain from issuing a signal in a particular month that is not to be followed by a crisis (within the next $\mathrm{n}$ months, example 24 months), 
so that $\mathrm{B}=0$ and $\mathrm{D}>0$. For sure, none of the indicators fit the profile of a perfect indicator, but the matrix will be a useful reference to assess how close or how far is each indicator from that profile.

Table 1. The Performance of Individual Indicator

by Using Matrix Crisis-Signal Framework

\begin{tabular}{lcc}
\hline & Crisis $(\mathbf{C}=\mathbf{1})$ & No Crisis $(\mathbf{C}=\mathbf{0})$ \\
\hline Signal Issued $(S=1)$ & A & B \\
No Signal Issued $(S=0)$ & C & D \\
\hline
\end{tabular}

Source: Kaminsky, et. al (1998)

\section{Determining evaluation criteria}

This paper employs six evaluation criteria in order to assess the performance of leading variables which was identified through crisis-signal framework, as follows: First, The proportion of an observation correctly called $=\frac{A+D}{(B+D)+(A+C)}$, defined as the proportion that all observations correctly bring information about crisis and not crisis. This implies that the higher proportion will lead to best evaluation criteria.

Second, the noise-to-signal-ratio $=\frac{B /(B+D)}{A /(A+C)}$, it measures the false signals as a ratio of the good signals issued. The selection rule is to pick the variable or model that minimizes the noise to signal ratio (NTS). Third, the proportion of a crisis correctly called $=\frac{A}{(A+C)}$, defined as the proportion of a crisis happened once the signal was issued. Thus, the higher of its proportion would be fitting of a perfect indicator in signaling the crisis. Fourth, the proportion of a false alarm of total alarms issued $=\frac{B}{(A+B)}$, given that an individual indicator exposes a frequent false signal. Thus, the lower of its proportion would be good to minimize the panic behavior in the markets. Fifth, the proportion of a crisis given an alarm issued = $\frac{A}{(A+B)}$, given that an individual indicator generates different signals. This criterion is to select indicators that can maximize the probability of a crisis, given a signal was issued as alarm. Sixth, the proportion of probability of a crisis, but given no alarm issued $=\frac{C}{(C+D)}$, given the signal is important, an occurence of crisis without signals wa expected small as possible.

\section{Determining signaling horizon}

This paper involves various signaling horizons. This signaling horizons reflect a range of period that has ability providing time frame for anticipating a crisis. Kaminsky (1997) uses 24 months signaling horizon. He argued that the longer 
signaling horizon would enable policy makers to anticipate a crisis. Meanwhile, Bussiere and Fratzscher (2002) set 12 and 18 month as signaling horizon. They argues that various time horizons would provide the best achievable trade-off between missing a crisis and a wrong signal. In addition, this paper adds another 3 and 6 months as signaling horizons considering that a crisis is difficult to be predicted. Providing short horizon enables policy makers to react immediately as crisis starts to build up.

\section{Determining thresholds}

The economy evolves through phases of booms and recession. This change in phase of a particular series is captured empirically by finding a "threshold". The economy turns a fluctuation by examining a given indicator into a signaling process of an upcoming recession or a crisis. The selected threshold is the one that can minimize the noise-to-signal ratio (NTR) of a particular indicator.

\section{Determining leading indicators}

Vulnerabilities in a financial system can build overtime. Meanwhile, the system's operation depends on macroeconomic developments, given interconnectedness and complexity nature in the financial system. Consequently, shocks on macroeconomic indicators can affect individual financial institutions. Given that interconnectedness occurs in the financial system, developing a set of indicators is important to help detecting in advance macroeconomic and financial vulnerabilities affecting the banking system. Unfortunately, there is no clear-cut on macroeconomic model to analyze the macro-fundamental that are relevant as leading indicators for the resilience of Islamic banking. This paper adopts some variables that are suggested by Susatyo (2002) in developing an EWS for currency crises. He used data since $1990-2000$ in monthly basis by using 14 variables to identify leading indicators. He found that out of 14 variables, only M2/Reserve, inflatio rate, credit growth, and real effective exchange rate that were relevant as leading indicator for currency crises in Indonesia. Similarly, Garcia and Herrera (1999) studied on an early warning for currency crisis and suggested M2/reserve, credit growth, real effective exchange rate, and inflation rate. Although these leading leading indicators are used for currency crises, Jacobs and Kuper (2004) argued that banking crises may be associated with currency crises trough a number of channels of causation or the other way round. In other words, these leading indicators could be applicable for the banking crises. Therefore, these leading indicators will be used in the case for detecting the resilience of Islamic banking in Indonesia, as follows: 
First, $\mathrm{M}_{2} /$ Reserve $\left(\mathrm{M}_{2}\right.$ Res $)$ is used to capture the vulnerability in the economy due to the sudden capital outflows. The higher ratio $\mathrm{M}_{2}$ /total reserve denotes the increase of likelihood of Islamic banking crisis or reducing the resilience of Islamic banking. Second, credit growth (CG) is defined as the percentage change of the total credit approved in several banks, including national banks, regional development banks, national private banks, and foreign banks. This indicators indicates the fast expansion of loans extension which later would give additional default risk in the banking system. In addition, credit growth which is considered 'excessive' may lead to systemic risk, given that inconnectedness in the financial system. Therefore, rapid credit growth episode can increase likelihood of systemic risk and deterioration of banks' balance sheets. Third, real effective exchange rate (REER) is obtained by deflating nominal exchange rate with the ratio of standardized inflation rates (based on a certain base year period). Consumer price index (CPI) United States of America over CPI of Indonesia are used to obtain the standardized ratio of inflation rates. REER is important to measure comparative changes in a country's real economic circumtances compared other country. If the REER of a country shows a downward trend (overvaluation), it implies that the price of domestic country is higher that foreign price, vice versa. Hence, the overvaluation in the real exchange rate may create an increased possibility of crises due to a domestic country prefers to imports to exports. Fourth, inflation rate (INF) is defined as the difference of CPI between current CPI and previous CPI after being standardized. The higher degree of inflation implies that likelihood of crises would occur due to eroding purchasing power of parity.

Table 2.

Summary of the Indicator, Tranformation, Frequency, and Threshold Position

\begin{tabular}{cccc}
\hline Variable & Transformation & Frequency & Threshold Position \\
\hline M2/Res & Level & Monthly Data & Over Zero Line \\
CG & 12 month change & Monthly Data & Over Zero Line \\
REER & Level & Monthly Data & Below Zero Line \\
INF & 12 month change & Monthly Data & Over Zero Line \\
\hline
\end{tabular}


Result and Discussion

The Performance of Islamic Banking Resilience Index

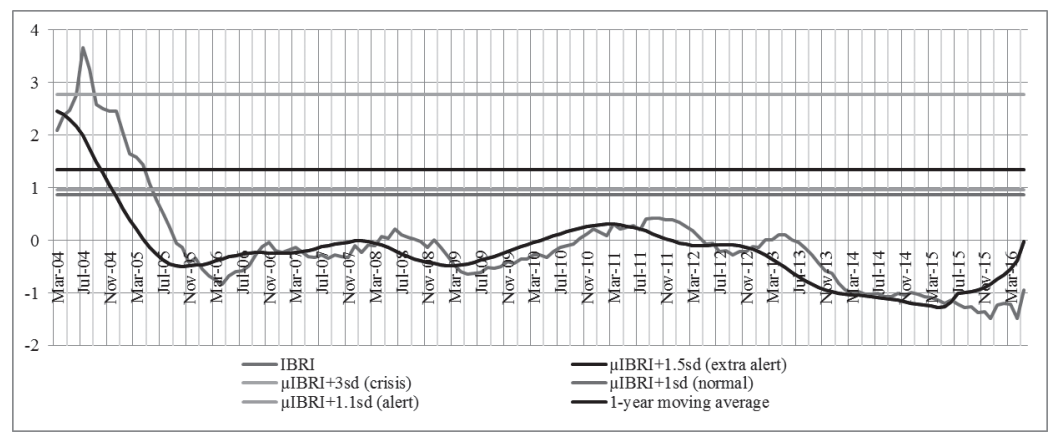

Figure 1. Islamic Banking Resilience Index (IBRI)

Figure 1 shows the Islamic Banking Resilience Index (IBRI) since March 2004 till May 2016. Generally, IBRI measures and monitors the level of resilience of Islamic banking in Indonesia. Empirically, IBRI is capable of providing information on the ups and downs in the resilience of Islamic banking with respect of various economic vulnerabilities indicators. Figure 1 also presents facts that in 2004, the resilience of Islamic banking was worst, indicated the IBRI is above green line, which was in crisis area. But, the trend is gradually decreasing and until may 2016, the resilience is below normal area (purple line). In addition, according to orange line, which reflects the 1-year moving average of IBRI, the trend is increasing and showing excessive risk taking starts to happen in Islamic banking. Hence, the policy makers should keep prudent in regulating Islamic banking operations in Indonesia.

In 2005, Islamic banks showed dark performances. It was due to Indonesia experienced a mini crisis. The 'mini crisis' is shown by two main indicators, namely the banks' profitability and non-performing financing. In terms of net profitability, overall banking industry plummeted around 18,3\% from Rp 29,46 trillion in 2004 to $\mathrm{Rp} 24,9$ trillion in 2005 . Some factors were also believed contributing on stressing of profit level, such as domestic oil price increase for around $126,6 \%$, inflation rates $18 \%$, and policy rate Bank Indonesia 12,75\%. These condition affected banking operations, including in Islamic banks which were connected with external adverse shocks. In addition, in terms of non performing financing, it raised for $8,2 \%$ in 2005 from 4,5\% in 2004. This percentage exceeded the stipulated NPL by Bank Indonesia around 5 percents. This condition reflects that in 2005 Indonesia's economy was hit by moderate crisis as shown in the figure 1 . 


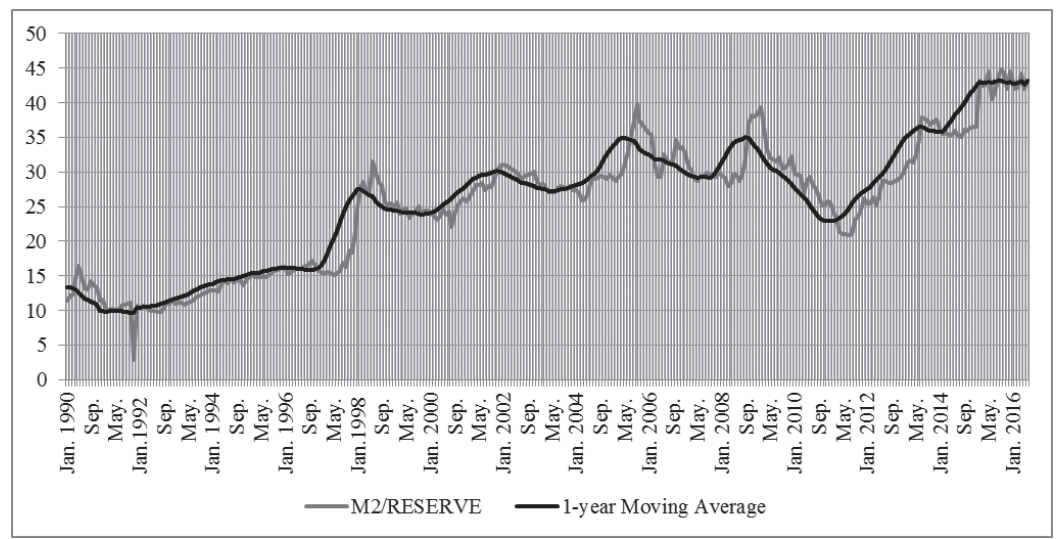

Figure 2. The Performance of M2/Reserve in Indonesia, Period 1990 - 2016 (Monthly Basis)

Figure 2 shows the performance of M2/res in Indonesia over 1990 - 2016 in monthly basis. According to the figure, the red line, which is the 1 year moving average, is exceeded several times by the blue line ( $\mathrm{M} 2 /$ res variable). It indicates that $\mathrm{M} 2 /$ res is pressured and possibly got shocks as economic deteriorated. Period of 1998, 2005, 2008, are the years where economic and financial distress hit severely into Indonesia's economy, as shown in the figure 1.

Figure 3 shows the performance of credit growth in Indonesia over the period of 1990-2016 in monthly basis. Figure 3 obviously presents some abnormal behavior of credit growth, indicated by exceeding the red line. There are six period where credit growth is considered showing abnormal behavior, namely in 1990, 1998, 2000, 2006, 2008, and 2014. In all these abnormal period, credit growth seems to be declining once it grows rapidly or excessively. Hence, credit growth can be seen to represent the period of boom and burst in the financial cycle.

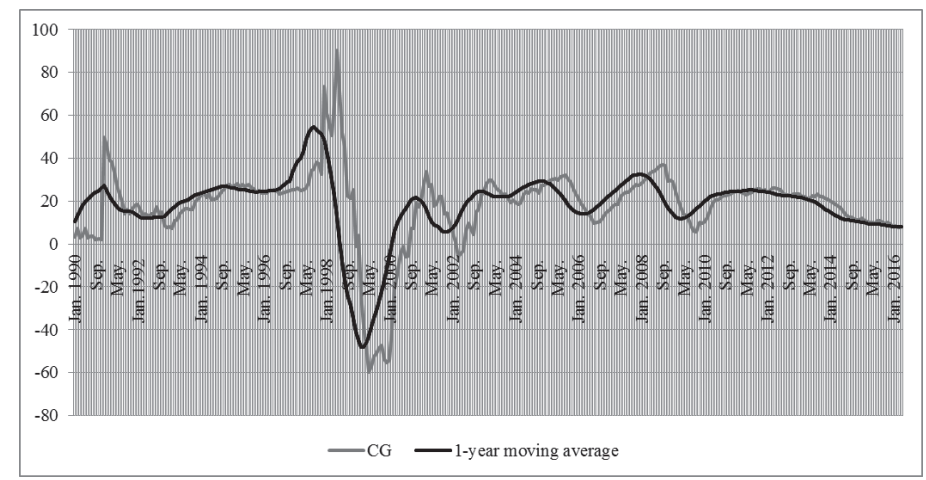

Figure 3. The Performance of Credit Growth in Indonesia, Period 1990 - 2016 (Monthly Basis) 
Figure 4 shows the performance of REER in Indonesia since 1990-2016 in monthly basis. Interestingly, over the period of observation, REER presents an abnormal behavior only during Asian financial crisis in 1998. It reflects during this crisis, Indonesia's economy is hit severely by crisis so lossing its competitiveness eventhough theoretically REER is undervalued compared to foreign prices.

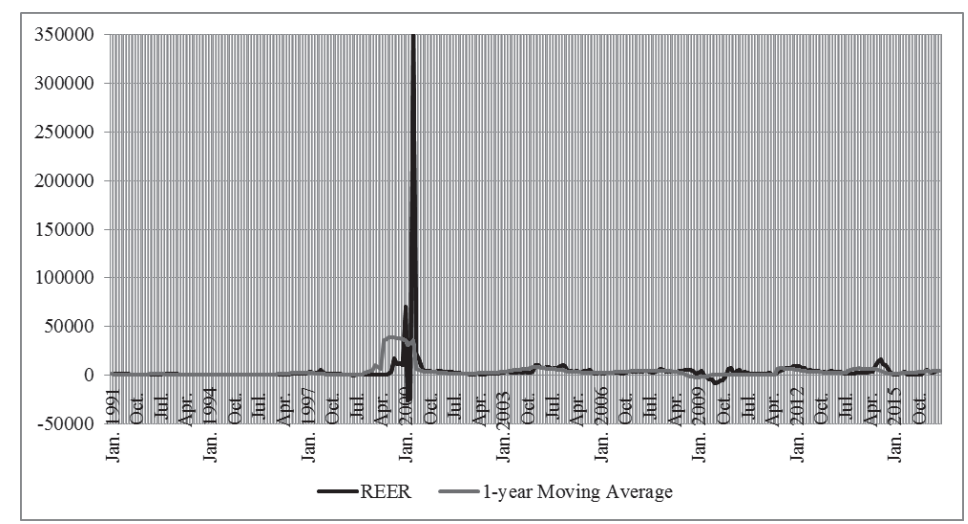

Figure 4. The Performance of Real Effective Exchange Rate in Indonesia, Period 1990 - 2016 (Monthly Basis)

Figure 5 shows the performance of inflation rate in Indonesia since 1990 to 2016. During Asian financial crisis, inflation rate was extremely high, but gradually decreases and shows a low level by 2016. Likewise, during global financial crises in 2007-2008, inflation rate was quite high and exceeded the red line. Hence, an increase in inflation rate could be a clear indication of a country's deterioration.

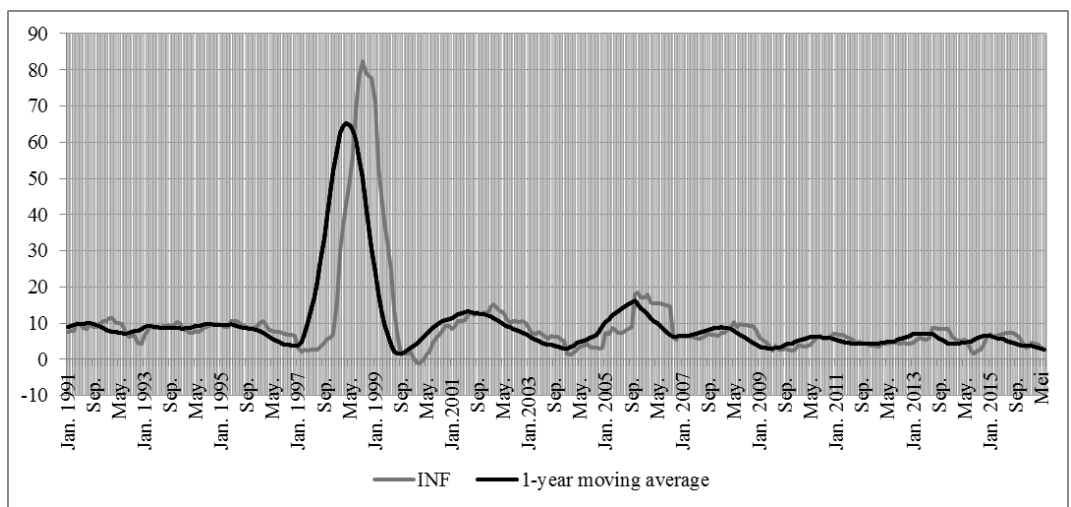

Figure 5. The Performance of Inflation rate in Indonesia, Period 1990 - 2016 in Monthly Basis 


\section{The Signal Generating Mechanism on Several Leading Variables}

This section explains the performance of every leading variable by using signal exytraction signal approach. This paper applies several threshold multiplier, namely according to kaminsky (1996) - 3 standard deviation, Garcia (1999) - 1.5 standard deviation, Park (2001) - 1.1 standard deviation, and Lestano, et.al (2003) - 1.0 standard deviation. In addition, to evaluate the predictive power of every leading variable in detecting crisis, this paper uses different time horizon, namely 3 month, 6 month, 12 month, 18 month, and 24 month.

Table 3. Evaluation of M2/Res Variable

\begin{tabular}{|c|c|c|c|c|c|c|c|c|c|c|c|c|c|c|c|c|c|c|c|c|c|c|c|c|}
\hline \multirow{2}{*}{ M2/Res } & \multicolumn{6}{|c|}{ Kaminsky } & \multicolumn{6}{|c|}{ Garcia } & \multicolumn{6}{|c|}{ Park } & \multicolumn{6}{|c|}{ Lestano } \\
\hline & 24 & 18 & 12 & 6 & 3 & Avrg & 24 & 18 & 12 & 6 & 3 & Avrg & 24 & 18 & 12 & 6 & 3 & Avrg & 24 & 18 & 12 & 6 & 3 & Avrg \\
\hline $\begin{array}{l}\text { Noise to Signal } \\
\text { Ratio }(-)\end{array}$ & 0 & 0 & 0 & 0 & 0 & 0 & 0,59 & 0,34 & 0,35 & 0,22 & 0,15 & 0,33 & 1,24 & 0,79 & 0,76 & 0,55 & 0,39 & 0,75 & 1,2 & 0,9 & 0,7 & 0,6 & 0,4 & 0,76 \\
\hline $\begin{array}{l}\text { The proportion } \\
\text { of observations } \\
\text { correctly (+) }\end{array}$ & 0 & 0 & 0 & 0 & 0 & 0 & 0,07 & 0,12 & 0,14 & 0,19 & 0,33 & 0,17 & 0,06 & 0,10 & 0,11 & 0,15 & 0,21 & 0,13 & 0,08 & 0,10 & 0,14 & 0,17 & 0,25 & 0,15 \\
\hline $\begin{array}{l}\text { The proportion } \\
\text { of crises } \\
\text { correctly (+) }\end{array}$ & 0 & 0 & 0 & 0 & 0 & 0 & 0,42 & 0,38 & 0,41 & 0,48 & 0,54 & 0,45 & 0,42 & 0,38 & 0,46 & 0,52 & 0,61 & 0,48 & 0,39 & 0,38 & 0,41 & 0,51 & 0,59 & 0,45 \\
\hline $\begin{array}{l}\text { The proportion } \\
\text { of false alarm } \\
\text { of total alarms } \\
\text { issued (-) }\end{array}$ & 0 & 0 & 0 & 0 & 0 & 0 & 0,57 & 0,61 & 0,58 & 0,52 & 0,46 & 0,55 & 0,57 & 0,61 & 0,54 & 0,47 & 0,38 & 0,52 & 0,60 & 0,61 & 0,59 & 0,49 & 0,41 & 0,54 \\
\hline $\begin{array}{l}\text { The proportion } \\
\text { of crisis given an } \\
\text { alarm issued (+) }\end{array}$ & 0,11 & 0,07 & 0,07 & 0,04 & 0,02 & 0,06 & 0,43 & 0,33 & 0,31 & 0,17 & 0,08 & 0,26 & 0,63 & 0,55 & 0,46 & 0,32 & 0,18 & 0,43 & 0,65 & 0,59 & 0,48 & 0,33 & 0,19 & 0,45 \\
\hline $\begin{array}{l}\text { The proportion } \\
\text { of probability of } \\
\text { crisis given no } \\
\text { alarm issued (-) }\end{array}$ & 1 & 1 & 1 & 1 & 1 & 1 & 0,94 & 0,93 & 0,92 & 0,92 & 0,91 & 0,93 & 0,92 & 0,90 & 0,89 & 0,89 & 0,88 & 0,90 & 0,91 & 0,89 & 0,88 & 0,87 & 0,86 & 0,88 \\
\hline
\end{tabular}

Table 3 shows the results of evaluations of the M2/Res as leading indicator by using signal approach. The main conclusion is that kaminsky is the best option to be used as leding indicator in various time horizon. The lowest level of noise to signal indicates that kaminsky's approach is capable of minimizing wrong signal and miss signal in detecting crisis. According to table 3, indicator $\mathrm{M} 2 /$ res can be used to detect either in the short or long window period. It means that $\mathrm{M} 2 /$ res is so relevant to show signs for some possibilities of any upcoming Islamic banking instability. The M2/res indicator is closely related with exchange rate fluctuations. Given that exchange rate deeply depreciated, central bank will intervene seriously and trigger reserve shortage in the central bank. Therefore, M2/res indicator is considered as very sensitive sign to oversee the possibility of abnormal behavior in Islamic banking operations.

Table 4 explains some evaluations criteria of credit growth variable as leading indicator by using signal extraction approach. According to the table 4, kaminsky's approach shows the lowest value of noise to signal ratio, specifically in 3 month time horizon. It implies that policy makers should aware in a shortly period concerning the behavior of credit growth in Indonesia. The excessive credit growth can endanger 
through overheating the business cycle. The boom and burst of business cycle are due to business cycle showing cyclical ups and downs which is then called as procyclicality behavior. The procyclicality behavior is fueled by credit extension that becomes main sources of economic transactions in the modern era. Therefore, the 3 month windows period indicates that credit turnovers are fast and may lead to Islamic banking stress.

Table 4. Evaluation of Credit Growth Variable

\begin{tabular}{|c|c|c|c|c|c|c|c|c|c|c|c|c|c|c|c|c|c|c|c|c|c|c|c|c|}
\hline \multirow{2}{*}{ CG } & \multicolumn{6}{|c|}{ Kaminsky } & \multicolumn{6}{|c|}{ Garcia } & \multicolumn{6}{|c|}{ Park } & \multicolumn{6}{|c|}{ Lestano } \\
\hline & 24 & 18 & 12 & 6 & 3 & Avrg & 24 & 18 & 12 & 6 & 3 & Avrg & 24 & 18 & 12 & 6 & 3 & Avrg & 24 & 18 & 12 & 6 & 3 & Avrg \\
\hline $\begin{array}{l}\text { Noise to Signal } \\
\text { Ratio }(-)\end{array}$ & 0,12 & 0,07 & 0,07 & 0,04 & 0,02 & 0,07 & 0,59 & 0,45 & 0,33 & 0,12 & 0,18 & 0,34 & 0,24 & 0,50 & 0,40 & 0,15 & 0,29 & 0,30 & 0,34 & 0,61 & 0,24 & 0,22 & 0,35 & 0,35 \\
\hline $\begin{array}{l}\text { The proportion } \\
\text { of observations } \\
\text { correctly }(+)\end{array}$ & 0,03 & 0,04 & 0,04 & 0,09 & 0,20 & 0,08 & 0,02 & 0,02 & 0,03 & 0,06 & 0,10 & 0,04 & 0,05 & 0,03 & 0,05 & 0,10 & 0,08 & 0,06 & 0,04 & 0,03 & 0,05 & 0,10 & 0,08 & 0,06 \\
\hline $\begin{array}{l}\text { The proportion of } \\
\text { crises correctly }(+)\end{array}$ & 0,5 & 0,5 & 0,5 & 0,5 & 0,5 & 0,5 & 0,43 & 0,43 & 0,43 & 0,33 & 0,63 & 0,45 & 0,13 & 0,28 & 0,25 & 0,23 & 0,54 & 0,29 & 0,16 & 0,31 & 0,19 & 0,28 & 0,57 & 0,30 \\
\hline $\begin{array}{l}\text { The proportion } \\
\text { of false alarm } \\
\text { of total alarms } \\
\text { issued (-) }\end{array}$ & 0,5 & 0,5 & 0,5 & 0,5 & 0,5 & 0,5 & 0,57 & 0,57 & 0,57 & 0,67 & 0,38 & 0,55 & 0,87 & 0,71 & 0,75 & 0,76 & 0,45 & 0,71 & 0,84 & 0,69 & 0,81 & 0,71 & 0,43 & 0,69 \\
\hline $\begin{array}{l}\text { The proportion } \\
\text { of crisis given an } \\
\text { alarm issued (+) }\end{array}$ & 0,11 & 0,07 & 0,07 & 0,03 & 0,01 & 0,06 & 0,43 & 0,37 & 0,30 & 0,19 & 0,09 & 0,28 & 0,61 & 0,55 & 0,47 & 0,32 & 0,19 & 0,43 & 0,63 & 0,57 & 0,50 & 0,34 & 0,20 & 0,45 \\
\hline $\begin{array}{l}\text { The proportion } \\
\text { of probability of } \\
\text { crisis given no } \\
\text { alarm issued (-) }\end{array}$ & 0,99 & 0,99 & 0,99 & 0,99 & 0,99 & 0,99 & 0,98 & 0,98 & 0,98 & 0,98 & 0,97 & 0,98 & 0,96 & 0,97 & 0,96 & 0,95 & 0,96 & 0,96 & 0,96 & 0,97 & 0,96 & 0,95 & 0,95 & 0,96 \\
\hline
\end{tabular}

Table 5. Evaluation of REER Variable

\begin{tabular}{|c|c|c|c|c|c|c|c|c|c|c|c|c|c|c|c|c|c|c|c|c|c|c|c|c|}
\hline \multirow{2}{*}{ REER } & \multicolumn{6}{|c|}{ Kaminsky } & \multicolumn{6}{|c|}{ Garcia } & \multicolumn{6}{|c|}{ Park } & \multicolumn{6}{|c|}{ Lestano } \\
\hline & 24 & 18 & 12 & 6 & 3 & Avrg & 24 & 18 & 12 & 6 & 3 & Avrg & 24 & 18 & 12 & 6 & 3 & Avrg & 24 & 18 & 12 & 6 & 3 & Avrg \\
\hline $\begin{array}{l}\text { Noise to Signal } \\
\text { Ratio (-) }\end{array}$ & 0 & 0 & 0 & 0 & 0 & 0 & 0,50 & 0,56 & 0,43 & 0,27 & 0,15 & 0,38 & 0,64 & 0,54 & 0,68 & 0,73 & 0,43 & 0,60 & 0,63 & 0,65 & 0,98 & 0,86 & 0,66 & 0,76 \\
\hline $\begin{array}{l}\text { The proportion } \\
\text { of observations } \\
\text { correctly }(+)\end{array}$ & 0 & 0 & 0 & 0 & 0 & 0 & 0,05 & 0,06 & 0,08 & 0,13 & 0,22 & 0,11 & 0,17 & 0,20 & 0,16 & 0,15 & 0,21 & 0,18 & 0,22 & 0,23 & 0,16 & 0,18 & 0,21 & 0,20 \\
\hline $\begin{array}{l}\text { The proportion of } \\
\text { crises correctly }(+)\end{array}$ & 0 & 0 & 0 & 0 & 0 & 0 & 0,39 & 0,47 & 0,50 & 0,53 & 0,59 & 0,49 & 0,27 & 0,30 & 0,42 & 0,59 & 0,63 & 0,44 & 0,26 & 0,33 & 0,47 & 0,61 & 0,70 & 0,47 \\
\hline $\begin{array}{l}\text { The proportion } \\
\text { of false alarm } \\
\text { of total alarms } \\
\text { issued (-) }\end{array}$ & 0 & 0 & 0 & 0 & 0 & 0 & 0,61 & 0,52 & 0,50 & 0,53 & 0,59 & 0,49 & 0,72 & 0,70 & 0,57 & 0,41 & 0,37 & 0,55 & 0,73 & 0,66 & 0,53 & 0,38 & 0,30 & 0,52 \\
\hline $\begin{array}{l}\text { The proportion } \\
\text { of crisis given an } \\
\text { alarm issued (+) }\end{array}$ & 0,11 & 0,07 & 0,11 & 0,04 & 0,02 & 0,07 & 0,43 & 0,38 & 0,29 & 0,18 & 0,08 & 0,27 & 0,61 & 0,53 & 0,46 & 0,32 & 0,18 & 0,42 & 0,61 & 0,54 & 0,52 & 0,34 & 0,21 & 0,44 \\
\hline $\begin{array}{l}\text { The proportion } \\
\text { of probability of } \\
\text { crisis given no } \\
\text { alarm issued (-) }\end{array}$ & 1 & 1 & 1 & 1 & 1 & 1 & 0,96 & 0,95 & 0,94 & 0,94 & 0,94 & 0,95 & 0,85 & 0,84 & 0,86 & 0,87 & 0,88 & 0,86 & 0,14 & 0,15 & 0,16 & 0,15 & 0,14 & 0,15 \\
\hline
\end{tabular}

Table 5 shows some evaluation criteria for Real Effective Exchange Rate (REER) variable as leading indicator. The results explains that noise to signal remains the lowest by using kaminsky's approach in all time horizon. It indicates that the predictive power in extracting signal is strong if setting a threshold according to kaminsky's approach. The REER indicator indicates the price of currency towards goods and services. The globalization has increased the volume of trade and portfolio 
transactions in real and financial markets. With that fast changing situation, the REER would greatly be sensitive towards international envirounment and therefore it needs to be monitored frequently as early warning indicator.

Table 6. Evaluation of Inflation Rate Variable

\begin{tabular}{|c|c|c|c|c|c|c|c|c|c|c|c|c|c|c|c|c|c|c|c|c|c|c|c|c|}
\hline \multirow{2}{*}{ INF } & \multicolumn{6}{|c|}{ Kaminsky } & \multicolumn{6}{|c|}{ Garcia } & \multicolumn{6}{|c|}{ Park } & \multicolumn{6}{|c|}{ Lestano } \\
\hline & 24 & 18 & 12 & 6 & 3 & Avrg & 24 & 18 & 12 & 6 & 3 & Avrg & 24 & 18 & 12 & 6 & 3 & Avrg & 24 & 18 & 12 & 6 & 3 & Avrg \\
\hline $\begin{array}{l}\text { Noise to Signal } \\
\text { Ratio }(-)\end{array}$ & 0,72 & 0 & 0,47 & 0,22 & 0,11 & 0,31 & 0,79 & 0,53 & 0,41 & 0,15 & 0,20 & 0,41 & 0,46 & 0,59 & 0,45 & 0,20 & 0,28 & 0,40 & 0,44 & 0,74 & 0,57 & 0,29 & 0,37 & 0,48 \\
\hline $\begin{array}{c}\text { The proportion } \\
\text { of observations } \\
\text { correctly }(+)\end{array}$ & 0,03 & 0 & 0,04 & 0,09 & 0,2 & 0,07 & 0,05 & 0,07 & 0,09 & 0,15 & 0,19 & 0,11 & 0,08 & 0,06 & 0,08 & 0,11 & 0,13 & 0,09 & 0,10 & 0,06 & 0,07 & 0,11 & 0,11 & 0,09 \\
\hline $\begin{array}{l}\text { The proportion of } \\
\text { crises correctly }(+)\end{array}$ & 0,86 & 1 & 0,86 & 0,86 & 0,87 & 0,89 & 0,52 & 0,47 & 0,5 & 0,37 & 0,65 & 0,50 & 0,22 & 0,33 & 0,33 & 0,28 & 0,55 & 0,35 & 0,2 & 0,37 & 0,37 & 0,35 & 0,6 & 0,38 \\
\hline $\begin{array}{l}\text { The proportion } \\
\text { of false alarm } \\
\text { of total alarms } \\
\text { issued (-) }\end{array}$ & 0,14 & 0 & 0,14 & 0,14 & 0,12 & 0,11 & 0,48 & 0,52 & 0,5 & 0,62 & 0,35 & 0,49 & 0,77 & 0,66 & 0,66 & 0,71 & 0,44 & 0,65 & 0,8 & 0,63 & 0,63 & 0,65 & 0,4 & 0,62 \\
\hline $\begin{array}{l}\text { The proportion } \\
\text { of crisis given an } \\
\text { alarm issued (+) }\end{array}$ & 0,10 & 0,07 & 0,07 & 0,03 & 0,01 & 0,06 & 0,41 & 0,36 & 0,28 & 0,18 & 0,08 & 0,26 & 0,61 & 0,53 & 0,46 & 0,32 & 0,17 & 0,42 & 0,62 & 0,55 & 0,49 & 0,34 & 0,18 & 0,43 \\
\hline $\begin{array}{l}\text { The proportion } \\
\text { of probability of } \\
\text { crisis given no } \\
\text { alarm issued (-) }\end{array}$ & 0,98 & 0,98 & 0,97 & 0,97 & 0,97 & 0,97 & 0,96 & 0,92 & 0,95 & 0,95 & 0,95 & 0,95 & 0,93 & 0,95 & 0,95 & 0,95 & 0,95 & 0,95 & 0,92 & 0,95 & 0,94 & 0,94 & 0,94 & 0,94 \\
\hline
\end{tabular}

Table 6 presents some evaluation criteria for inflation variable as leading indicator. The results clearly show that the predictive power of inflation variable is strong by using kaminsky's approach due to lowest noise to signal ratio. In terms of time horizon, the lowest noise is 18 month horizon. The longer of window horizon indicates that the level of inflation in Indonesia is controllable. It is shown by Bank Indonesias publication that over time the inflation rate is decreasing. In other words, inflation rate shows a stable trend and it implies that early warning signal can be made in the more longer window periods.

Table 7. The Summarize of Performance on Leading Indicators

\begin{tabular}{|c|c|c|c|c|c|c|}
\hline \multirow[b]{2}{*}{ Variable } & \multicolumn{6}{|c|}{ Evaluation Criteria } \\
\hline & $\begin{array}{l}\text { Noise to Signal } \\
\text { Ratio }(-)\end{array}$ & $\begin{array}{c}\text { The proportion of } \\
\text { observations correctly } \\
\text { called (+) }\end{array}$ & $\begin{array}{l}\text { The proportion } \\
\text { of crises correctly } \\
\text { called (+) }\end{array}$ & $\begin{array}{l}\text { The proportion of } \\
\text { false alarm of total } \\
\text { alarms issued (-) }\end{array}$ & $\begin{array}{l}\text { The proportion of } \\
\text { crisis given an alarm } \\
\text { issued }(+)\end{array}$ & $\begin{array}{l}\text { The proportion } \\
\text { of probability of } \\
\text { crisis given no } \\
\text { alarm issued (-) }\end{array}$ \\
\hline M2/Res & $\begin{array}{l}\text { Kaminsky - } 0 \\
(3,6,12,18,24)\end{array}$ & Garcia - 0,33 (3) & Park-0,61 (3) & $\begin{array}{l}\text { Kaminsky - } 0 \\
(3,6,12,18,24)\end{array}$ & Lestano - 0,65 (24) & $\begin{array}{c}\text { Lestano }-0,86 \\
\text { (3) }\end{array}$ \\
\hline CG & Kaminsky- 0,02 (3) & Kaminsky- 0,09 (6) & Garcia - $0.63(3)$ & $\begin{array}{l}\text { Kaminsky- } 0,5 \\
(3,6,12,18,24)\end{array}$ & Lestano - 0,63 (24) & $\begin{array}{c}\text { Park and } \\
\text { Lestano - } 0,95 \\
(3,6)\end{array}$ \\
\hline REER & $\begin{array}{l}\text { Kaminsky - } 0 \\
(3,6,12,18,24)\end{array}$ & Lestano - 0,23 (18) & Garcia - 0,59 (3) & $\begin{array}{l}\text { Kaminsky - } 0 \\
(3,6,12,18,24)\end{array}$ & Lestano-0,61 (24) & $\begin{array}{c}\text { Lestano }-0,61 \\
\quad(3,24)\end{array}$ \\
\hline INF & Kaminsky - 0 (18) & Garcia - 0,19 (3) & Kaminsky - 1 (18) & Kaminsky - 0 (18) & Lestano - 0,62 (24) & $\begin{array}{c}\text { Lestano }-0,62 \\
(24)\end{array}$ \\
\hline
\end{tabular}

$(+),(-)$ denotes the value of each evaluation criteria, $(+)$ means bigger better, and $(-)$ means smaller better. $(3,6,12,18,24)$ indicates time windows horizons 
Table 7 summarizes the performance of several leading indicators included in the paper. Table 7 informs that four indicators are relevant as leading indicators for the resilience of Islamic banking in Indonesia. It is reflected by the low noise to signal ratio, almost zero, and low the proportion of false alarm of total alarms. These results are obtained by using kaminsky approach which employ 3, 6, 12, 18, 24 month time horizon. Looking at time horizon, the 3 month is seen as best horizon to predict the likelihood of a crises into Islamic banking. It seems relevant in the midst of fast changing of current domestic and global economy. The short time horizon indicates the need for policy makers to prepare early anticipation as macrofinancial variables start to behave abnormal. Meanwhile, lestano's approach is consistently able to capture best result on the proportion of crisis given an alarm. It implies that this approach is suitable to detect a signal followed by a crisis in the following 24 month. Thereore, all indicators are able to send alarm signals for 24 months before a crisis and implies these indicators can make policy makers more well-prepared in designing crisis management protocol in Indonesia.

\section{Conclusion}

This paper basically attempts to build an early warning system for the resilience of Islamic banking in Indonesia. The Islamic Banking Resilience Index (IBRI) is developed to help monitoring and anticipating the potential vulnerabilities in Islamic banking. In addition, some selected macrofinancial indicators are employed, such as M2/reserve, credit growth, real effective exchange rate, and inflation rate. Technically the paper uses several level of thresholds which are able to capyure the level of resilience of Islamic banking in Indonesia. Moreover, some time horizon, such as 3, 6,12,18, and 24 months are incorporated to obtain predictive power of above selected macrofinancial variables in signaling a crisis.

This research suggests several findings, as follows: first, IBRI, which is composed of standardized deposit and financing since 2004 until 2016 in monthly basis, is able to figure out the level of resilience of Islamic banking. The level of resilience of Islamic banking was worst in 2004, but gradually decreased and stable in subsequent period. Interestingly, the resilience of Islamic banking was considered stable when the index was moving below the normal line during the global financial crises. Second, Some selected indicators, such as M2/reserve (M2res), credit growth (CG), real effective exchange rate (REER), and inflation rate (INF) empirically show a low noise to signal ratio (NSR). It means that these four variables are capable of signaling vulnerabilities due to adverse external shocks. 


\section{References}

Adiningsih, S., Setiawati, D. N., \& Sholihah. (2002). Macroeconomic Vulnerability in Indonesia. EADN Regional Project. Bangkok.

Bank Indonesia. Kewajiban Penyediaan Modal Minimum Bank Umum, Pub. L. No. 15/12/PBI/2013 (2013). Indonesia: Bank Indonesia.

Bussiere, M, and M. Fratzscher (2002). "Towards a New Early Warning System of Financial Crises", European Central Bank Working Paper, No. 145

Caprio, G. Jr. and Klingebiel, D. (1996), "Bank Insolvency: Bad luck, Bad Policy or Bad Banking?", Paper presented at the 1996 Annual Bank Conference on Development Economics, World Bank Economic Review, January 1997

Davis, E. and D., Karim (2008). "Comparing Early Warning Systems for Banking Crisis”, Journal of Financial Stability, 4, 89-120

Demirgüç-Kunt, A. and E. Detragiache (1998). 'The Determinants of Banking Crises: Evidence from Developing and Developed Countries", IMF Staff Papers, 45, 81-109.

Demirgüç-Kunt, A. and E. Detragiache. (2000). "Monitoring Banking Sector Fragility: A Multivariate Logit”, World Bank Economic Review, 14(2), 287307.

Duttagupta R. and P. Cashin (2011). "Anatomy of Banking Crises in Developing and Emerging Market Countries", Journal of International Money and Finance, 30, 354-376.

Eichengreen, B. and A. Rose (1998). "Staying Afloat When the Wind Shifts: External Factors and Emerging-Market Banking Crises”, NBER Working paper no. 6370, January

Glick, R. and M. Hutchison (2001). "Banking and Currency Crises: How Common Are Twins?” in R. Glick, R. Moreno and M. Spiegel (eds.), Financial Crises in Emerging Markets, Cambridge University Press, Cambridge, UK.

González-Hermosillo, B. (1999). "Determinants of Ex-Ante Banking System Distress: A Macro-Micro Empirical Exploration of Some Recent Episodes", IMF Working Paper 99/33, March.

Gurnain Pasricha, Tom Roberts, Ian Christensen \& Brad Howell (2013) Assessing Financial SystemVulnerabilities: An Early Warning Approach, Bank of Canada Review, Autumn 2013, pp. 10-19

Hardy, D. and C. Pazarbasioglu (1999), "Determinants and Leading Indicators of Banking Crises: Further Evidence”, IMF Staff Papers, 46, 3, 247-58.

Herrera, S., \& Garcia, C. (1999). User's Guide to an Early Warning System for 
Macroeconomic Vulnerability in Latin American Countries (No. 2233). Policy Research Working Paper. Washington DC. Retrieved from

Honohan, P. (1997), "Banking System Failures in Developing and Transition Countries: Diagnosis and Predictions”, Working Paper 39, Bank for International Settlements.

Hutchinson, M. (2002). "European Banking Distress and EMU: Institutional and Macroeconomic Risks”, Scandinavian Journal of Economics, 104(3), 365-389

Kaminsky, G., Kizondo, S., and Reinhart, C. M. (1998). Leading Indicators of Currency Crises. IMF Staff Papers Staff Papers, 45(1), 48.

Kaminsky, G.,L., and Reinhart, C. (1996). "Banking and Balance of Payment Crises: Models and Evidence". Washington DC: Board of Governor of the Federal Reserve System.

Kaminsky, G. and Reinhart, C.M. (1999),'The Twin Crises: the Causes of Banking and Balance of Payments Problems', American Economic Review, 89, 473-500

Kibritcioglu, Aykut, (2003) "Monitoring Banking Sector Fragility, The Arab Bank Review, Vol 5, No.2 October.

Lindgren, C. J., Garcia, C., and Saal, M. (1996), Bank Soundness and Macroeconomic Policy, International Monetary Fund, Washington DC.

Lestano, Jan Jacobs, and Gerard H. Kuper. (2003) “Indicators Of Financial Crises do Work!: An Early Warning System for Six Asian Countrie”, CCSO Working Paper 13, Department of Economics, University Of Groningen, Netherland.

Matthieu Bussiere \& Marcel Fratzscher (2006), Towards a new early warning system of financial crises, Journal of International Money and Finance 25, pp. 953973.

Manasse, Paolo , Roberto Savona \& Marika Vezzoli (2013) Rules of Thumb for Banking Crises in Emerging Markets, Quaderni - Working Paper DSE No. 872, University of Bologna, Italy.

Park, Won-Am. (2001) "An Indicators on the Sustainable Development of Korea”, Paper prepared for EADN meeting, Singapore, June 25-27, 2001.

Sachs, J. D., Tornell, A., and Velasco, A. (1996), "Financial Crises in Emerging Markets: the Lessons from 1995”, Working Paper 5576, National Bureau of Economic Research.

Wong, Jim and Wong, T. C. and Leung, Phyllis (2007) A Leading Indicator Model of Banking Distress - Developing an Early Warning System for Hong Kong and Other EMEAP Economies (December 18, 2007). Hong Kong Monetary Authority Working Paper No. 22/2007. 
Al-Iqtishad: Jurnal Ilmu Ekonomi Syariah (Journal of Islamic Economics) Vol. 9 (1), January 2017

Wong J, TC Wong \& P Leung (2010) Predicting banking distress in the EMEAP economies, Journal of Financial Stability, vol. 6, issue 3, pp.169-179

Yucel, E. (2011). A Review and Bibliography of Early Warning Models. Munich Personal RePEc Archive, (32893), 19. 